\title{
Acid Blue 92 (Leather Dye) Removal from Wastewater by Adsorption using Biomass Ash and Activated Carbon
}

\author{
Abhiti Purai ${ }^{1}$ and V. K. Rattan ${ }^{2, \star}$ \\ ${ }^{1}$ Centre for Environment and Vocational Studies, Panjab University Chandigarh-160014, India \\ ${ }^{2}$ Department of Chemical Engineering and Technology, Panjab University Chandigarh-160014, India \\ ^e-mail: vkrattanpu@yahoo.com \\ (Received December 16, 2009; Accepted February 3, 2010)
}

\begin{abstract}
The adsorption of Acid Blue 92 onto three low cost and ecofriendly biosorbents viz., cow dung ash, mango stone ash and parthenium leaves ash and commercial activated carbon have discussed in this work. The ash of all the mentioned bio-wastes was prepared in the muffle furnace at $500^{\circ} \mathrm{C}$ and all the adsorbents were stored in an air thermostat. Experiments at total dye concentrations of $10 \sim 100 \mathrm{mg} / \mathrm{L}$ were carried out with a synthetic effluent prepared in the laboratory. The parameters such as $\mathrm{pH}$ and dye concentration were varied. Equilibrium adsorption data followed both Langmuir and Freundlich isotherms. The results indicate that cow dung ash, mango stone ash and parthenium leaves ash could be employed as low-cost alternatives to commercial activated carbon in wastewater treatment for the removal of dye.
\end{abstract}

Keywords : Adsorption, Biomass ash, Activated carbon, Leather dye, Isotherms

\section{Introduction}

Tannery wastewater is a powerful pollutant. It can cause severe environmental problems related to its high chemical oxygen demand (COD) together with elevated chrome concentration and deep color content [1]. Synthetic dyes are widely used in many industries including leather dyeing and paper printing. Dyes are almost invariably toxic, and additionally a visible pollutant, so their removal from effluent stream is ecologically essential. The disposal of these wastes into the environment could be harmful since they reduce light penetration and have a derogatory effect on photosynthesis. In addition, most dyestuffs are designed to be resistant to environmental conditions such as light, heat, microbial attack and also to oxidizing agents [2]. For these reasons, the biodegradation of dyes is typically a slow process [3]. Consequently, considerable research for the best available technology for dye removal from aqueous solutions has been carried out in this study.

Dyes are easily visible even in highly diluted forms, posing an aesthetic problem and are toxic to human and aquatic life [4]. The presence of carcinogens has been reported in the combined wastewater of dyeing and printing units of Udaipur [5]. They pose a problem as they may be mutagenic and carcinogenic and can cause severe damage to human beings, such as dysfunction of the kidneys, reproductive system, liver, brain and nervous system [6].

Various techniques, such as chemical coagulation using alum, lime, ferric chloride, ferric sulphate, biosorption [7], oxidation methods using chlorine and ozone [8], biological treatment, floatation [9] and adsorption, have been employed to remove dyes from industrial effluents.

Adsorption techniques for wastewater treatment have become more popular owing to their efficiency in removal of pollutants stable for biological methods. Adsorption can produce high quality water while also being a process that is economically feasible [10].

The objective of the present work was to explore the potentialities of low cost and easily available bio-wastes i.e. cow dung ash, mango stone ash, parthenium leaves ash and activated carbon for the adsorptive removal of Acid Blue 92. The effects of some operating parameters ( $\mathrm{pH}$, dye concentration) on the biosorption process were investigated. In addition, the applicability of the Langmuir and Freundlich isotherm models were investigated.

\section{Experimental}

Adsorption studies were performed by the batch technique using biomass ash (low cost bio-waste) and activated carbon as the adsorbents without giving any pretreatment. A stock solution of the dye with a concentration of $1000 \mathrm{mg} / \mathrm{L}$ was prepared and dilutions were made with distilled water to make different concentrations $(10 \sim 100 \mathrm{mg} / \mathrm{L})$ for the adsorption studies. A known weight of the adsorbent $(1 \mathrm{~g})$ was added to $50 \mathrm{~mL}$ of each of the above concentration in $100 \mathrm{~mL}$ measuring flasks. These were placed in an air thermostat for 
Table 1. Concentration of Dye $\left(\mathrm{C}_{\mathrm{e}}\right)$ and Amount of Dye Adsorbed Per Gram of the Adsorbent $\left(\mathrm{q}_{\mathrm{e}}\right)$ at Different $\mathrm{pH}$

\begin{tabular}{|c|c|c|c|c|c|c|c|c|c|c|c|c|}
\hline \multirow{4}{*}{ Adsorbents } & \multicolumn{3}{|c|}{ Cow dung ash } & \multicolumn{3}{|c|}{ Mango stone ash } & \multicolumn{3}{|c|}{ Parthenium leaves ash } & \multicolumn{3}{|c|}{ Carbon } \\
\hline & \multicolumn{12}{|c|}{$\mathrm{q}_{\mathrm{e}}(\mathrm{mg} / \mathrm{g})$} \\
\hline & \multicolumn{3}{|c|}{$\mathrm{pH}$} & \multicolumn{3}{|c|}{$\mathrm{pH}$} & \multicolumn{3}{|c|}{$\mathrm{pH}$} & \multicolumn{3}{|c|}{$\mathrm{pH}$} \\
\hline & 6.90 & 4.95 & 8.61 & 6.90 & 4.95 & 8.61 & 6.90 & 4.95 & 8.61 & 6.90 & 4.95 & 8.61 \\
\hline $\mathrm{C}_{\mathrm{e}}(\mathrm{mg} / \mathrm{L})$ & $\mathrm{q}_{\mathrm{e}}$ & $\mathrm{q}_{\mathrm{e}}$ & $\mathrm{q}_{\mathrm{e}}$ & $\mathrm{q}_{\mathrm{e}}$ & $\mathrm{q}_{\mathrm{e}}$ & $\mathrm{q}_{\mathrm{e}}$ & $\mathrm{q}_{\mathrm{e}}$ & $\mathrm{q}_{\mathrm{e}}$ & $\mathrm{q}_{\mathrm{e}}$ & $\mathrm{q}_{\mathrm{e}}$ & $\mathrm{q}_{\mathrm{e}}$ & $\mathrm{q}_{\mathrm{e}}$ \\
\hline 10 & 0.48 & 0.48 & 0.48 & 0.42 & 0.42 & 0.425 & 0.395 & 0.495 & 0.41 & 0.43 & 0.4575 & 0.40 \\
\hline 20 & 0.98 & 0.90 & 0.99 & 0.73 & 0.695 & 0.745 & 0.635 & 0.85 & 0.77 & 0.71 & 0.83 & 0.71 \\
\hline 30 & 1.48 & 1.205 & 1.365 & 1.155 & 1.14 & 1.21 & 0.91 & 1.36 & 1.06 & 0.91 & 1.23 & 0.98 \\
\hline 40 & 1.835 & 1.415 & 1.905 & 1.455 & 1.66 & 1.61 & 1.31 & 1.84 & 1.49 & 1.14 & 1.6665 & 1.29 \\
\hline 50 & 2.17 & 1.76 & 2.205 & 2.13 & 1.78 & 2.06 & 1.9 & 2.33 & 1.96 & 1.31 & 1.63 & 1.38 \\
\hline 60 & 2.66 & 2.42 & 2.80 & 2.49 & 2.24 & 2.53 & 2.14 & 2.79 & 2.34 & 1.49 & 1.835 & 1.61 \\
\hline 70 & 3.185 & 3.065 & 3.315 & 2.82 & 3.06 & 2.705 & 2.7 & 3.31 & 2.71 & 1.69 & 2.05 & 1.93 \\
\hline 80 & 3.885 & 3.775 & 3.86 & 3.14 & 3.36 & 3.28 & 3.21 & 3.805 & 3.19 & 1.80 & 2.38 & 1.97 \\
\hline 90 & 4.265 & 4.315 & 4.16 & 3.80 & 3.86 & 3.65 & 3.50 & 4.29 & 3.56 & 1.97 & 2.40 & 2.265 \\
\hline 100 & 4.615 & 4.77 & 4.565 & 3.955 & 4.07 & 4.10 & 4.04 & 4.84 & 3.91 & 2.31 & 2.50 & 2.34 \\
\hline
\end{tabular}

$24 \mathrm{hr}$. with occasional shaking. The samples were then filtered and analyzed using UV-spectrophotometer. Wavelengths of different dyes were determined by $\lambda_{\max }$ method. The $\mathrm{pH}$ values of solutions were adjusted by addition of $\mathrm{H}_{2} \mathrm{SO}_{4}$ and $\mathrm{NaOH}$.

\section{Results and Discussion}

\subsection{Effect of initial dye concentration}

Table 1 indicates that the amount of dye adsorbed per gram of adsorbents increases with the increase in the dye concentration.

With increasing concentration of the dye the amount of dye adsorbed per gram of adsorbent increases and the increase varies for all the four adsorbents studied. It can be seen that cow dung ash showed better adsorption efficiency as compared to the other three adsorbents at neutral and basic $\mathrm{pH}(4.615 \mathrm{mg} / \mathrm{g}$ and $4.565 \mathrm{mg} / \mathrm{g})$ whereas at acidic $\mathrm{pH}$ parthenium leaves ash exhibited maximum adsorption efficiency $(4.84 \mathrm{mg} / \mathrm{g})$.

\subsection{Effect of $p H$}

$\mathrm{pH}$ is an important factor which determines the adsorption of dyes. A similar trend is observed for cow dung and parthenium leaves ash in Table 1 where amount adsorbed per gram of adsorbent is maximum at $\mathrm{pH} 4.95(4.77 \mathrm{mg} / \mathrm{g}$ and $4.84 \mathrm{mg} / \mathrm{g})$ and minimum at $\mathrm{pH} 8.61 \quad(4.565 \mathrm{mg} / \mathrm{g}$ and $3.91 \mathrm{mg} / \mathrm{g})$. Similarly, neutral $\mathrm{pH}(6.90)$ is least suited for mango stone ash and activated carbon $(3.955 \mathrm{mg} / \mathrm{g}$ and $2.31 \mathrm{mg} / \mathrm{g}$ ) though adsorption efficiency is more at basic $\mathrm{pH}$ $(4.1 \mathrm{mg} / \mathrm{g})$ for mango stone ash and at acidic $\mathrm{pH}(2.5 \mathrm{mg} / \mathrm{g})$ for activated carbon.

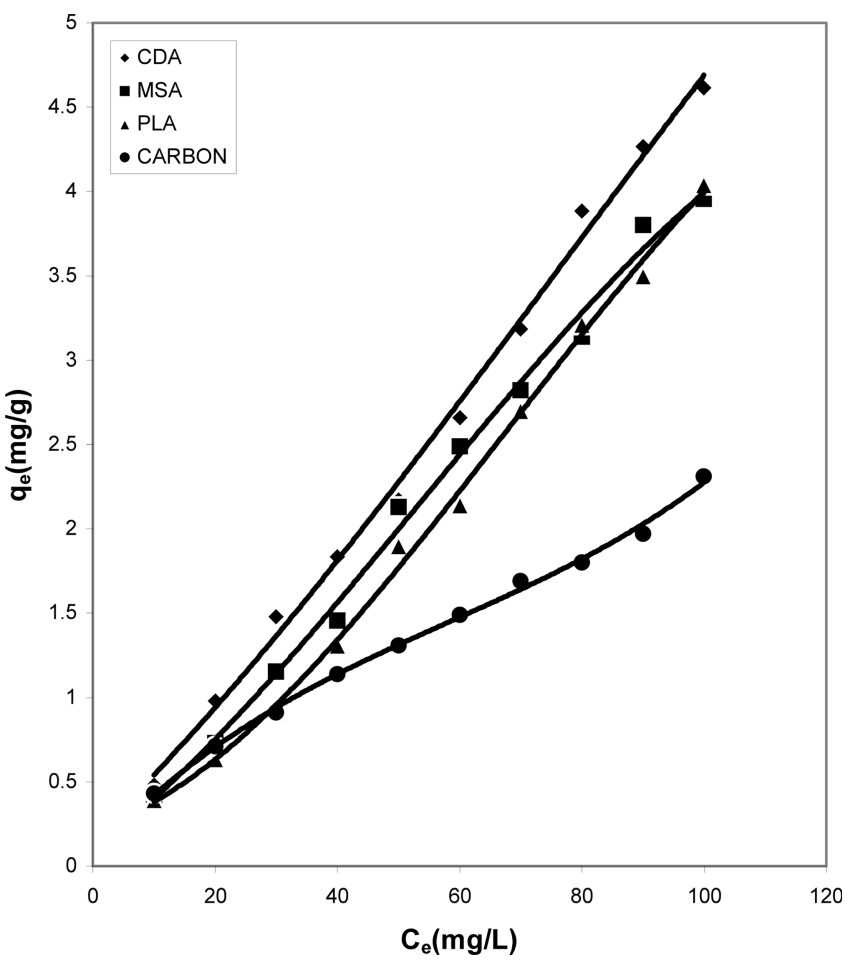

Fig. 1. Adsorption isotherm of Acid Blue 92 at $\mathrm{pH} 6.90$.

\subsection{Data fit for Simple Isotherms}

Figs. 1, 4 and 7 show that the experimental data fitted well to Polynomial Equation 1. The constants and standard deviation are given in Table 2 .

Figs. 1, 4 and 7 reveal the comparative adsorption of the dye on all the four adsorbents at different $\mathrm{pH}$ values. Maximum removal of dye was observed at $\mathrm{pH} 4.95$. Amongst all the four adsorbents activated carbon showed the 


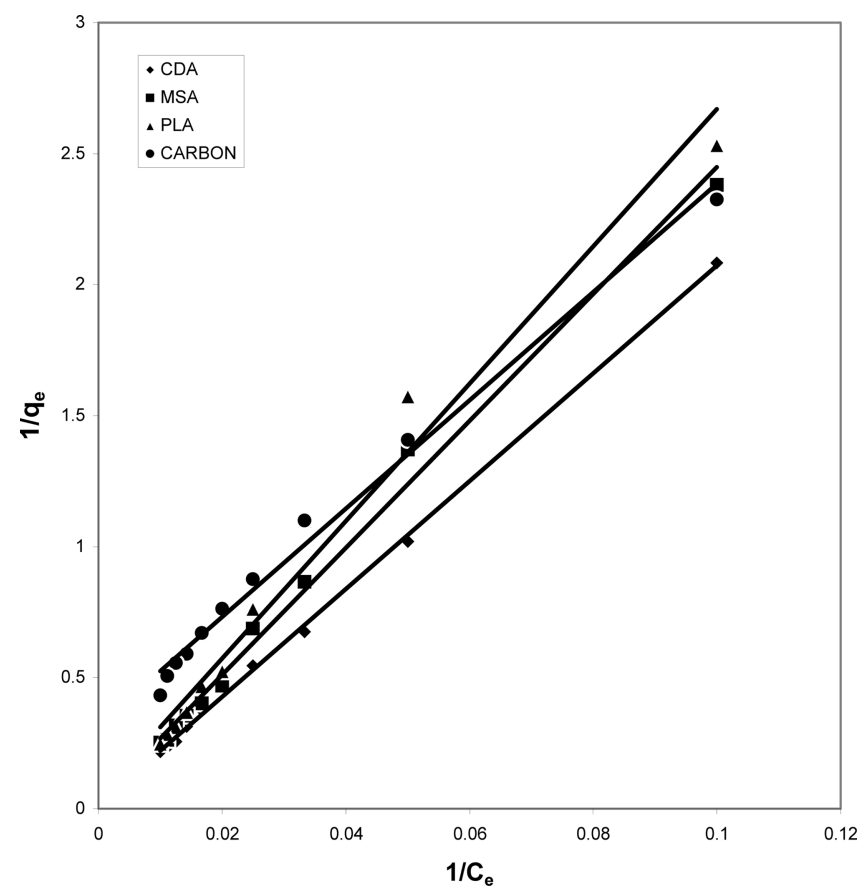

Fig. 2. Langmuir isotherm of Acid Blue 92 at pH 6.90.

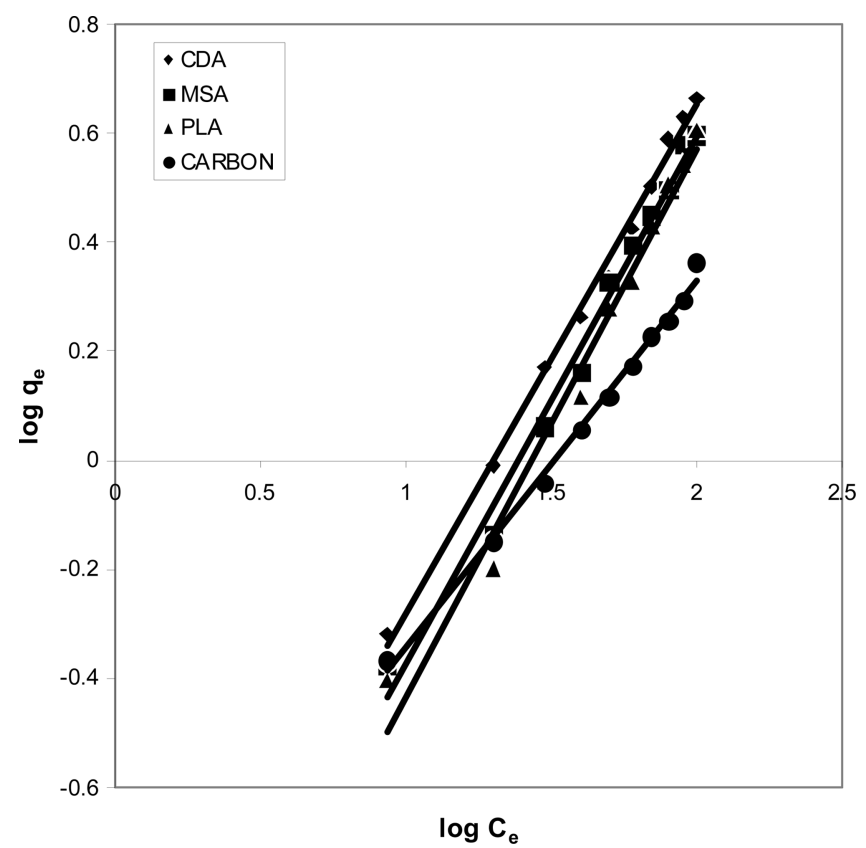

Fig. 3. Freundlich isotherm of Acid Blue 92 at pH 6.90.

least adsorption efficiency.

Fig. 10 shows that cow dung ash exhibits maximum color removal at higher concentration at acidic ph while at lower dye concentration the neutral and basic $\mathrm{pH}$ values are better. Fig. 11 clearly shows that basic $\mathrm{pH}$ dominates the adsorption capacity over the acidic and neutral $\mathrm{pH}$.

From Fig. 12, one can clearly see the capacity of

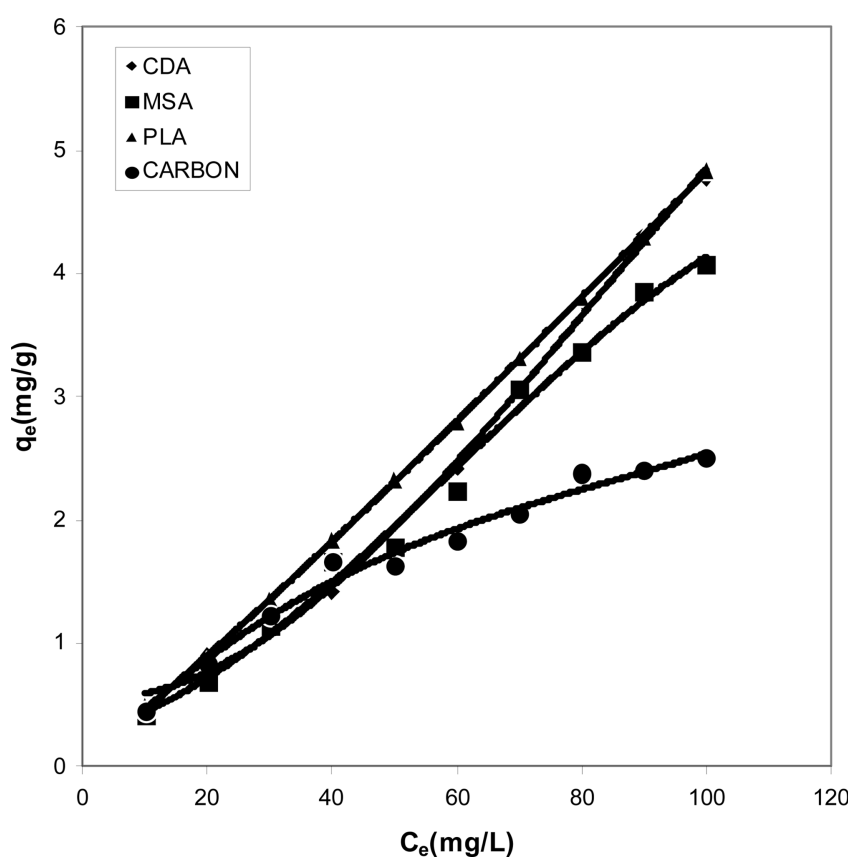

Fig. 4. Adsorption isotherm of Acid Blue 92 at pH 4.95.

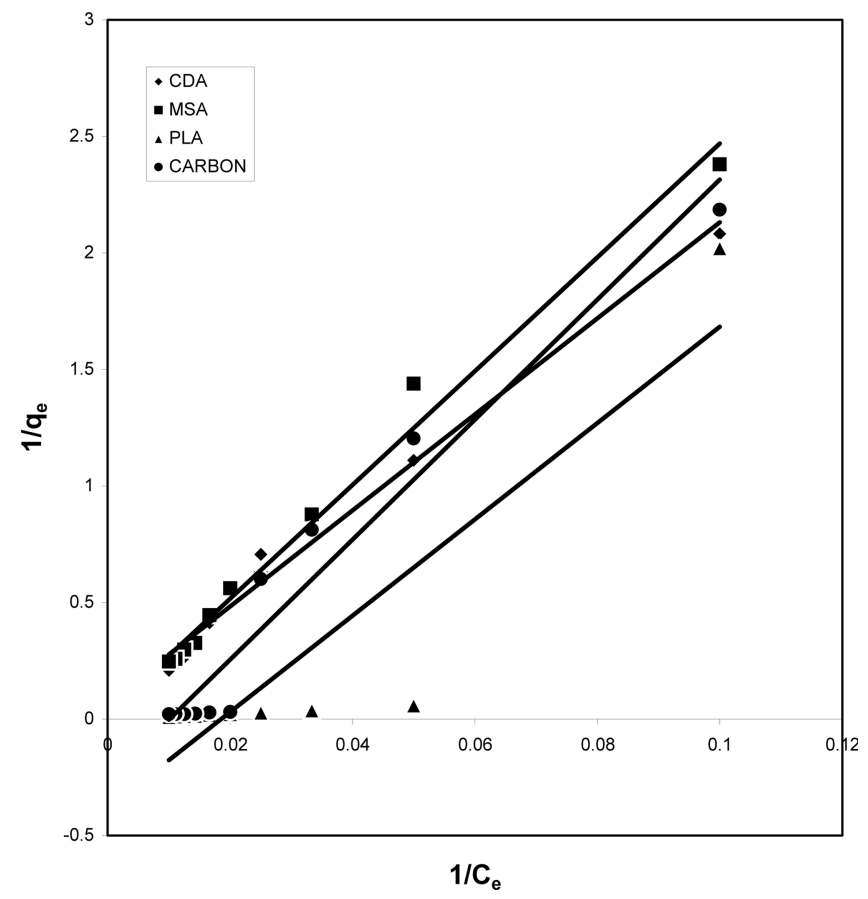

Fig. 5. Langmuir isotherm of Acid Blue 92 at pH 4.95.

parthenium leaves ash to adsorb maximum color at the acidic $\mathrm{pH}$ followed by the neutral and finally basic $\mathrm{pH}$. For activated carbon (Fig. 13) it can be drawn that simple isotherm shows the same behavior for all three $\mathrm{pH}$ values i.e. with increase in concentration the adsorption of dye increases. Both acidic and basic $\mathrm{pH}$ values are better suited 


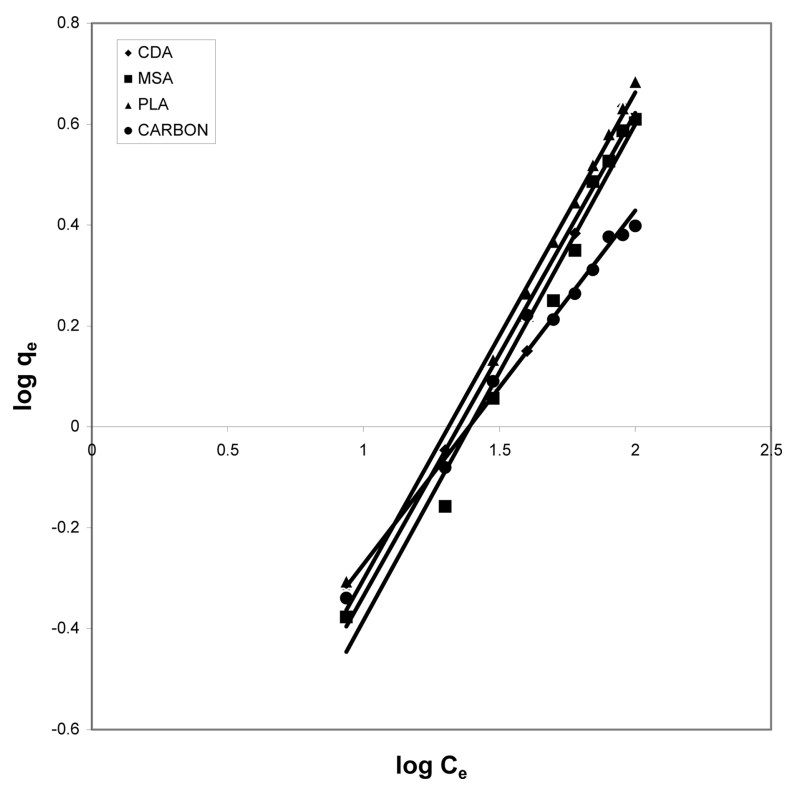

Fig. 6. Freundlich isotherm of Acid Blue 92 at pH 4.95.

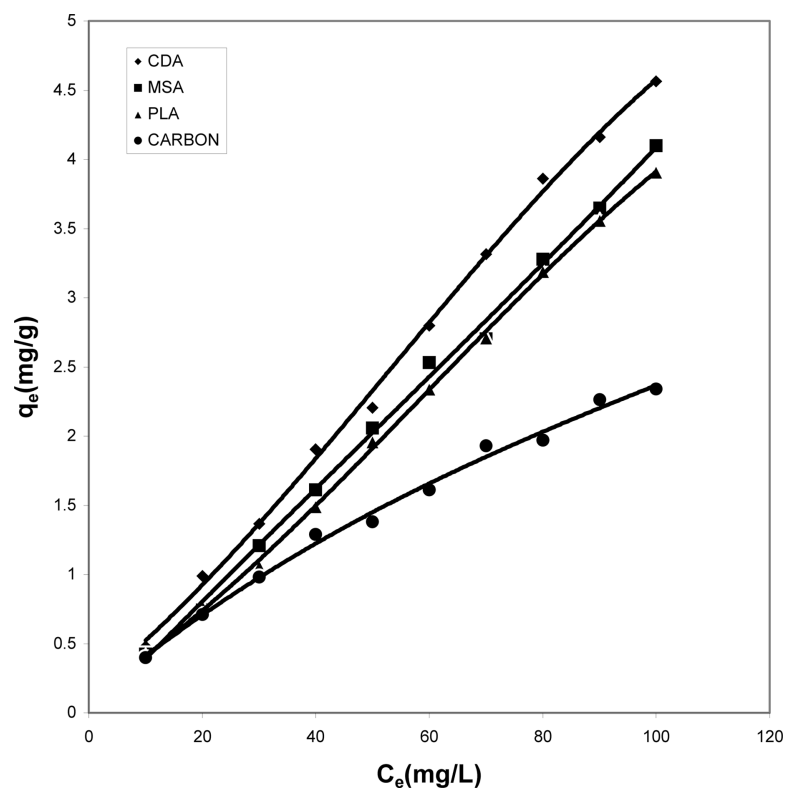

Fig. 7. Adsorption isotherm of Acid Blue 92 at $\mathrm{pH} 8.61$.

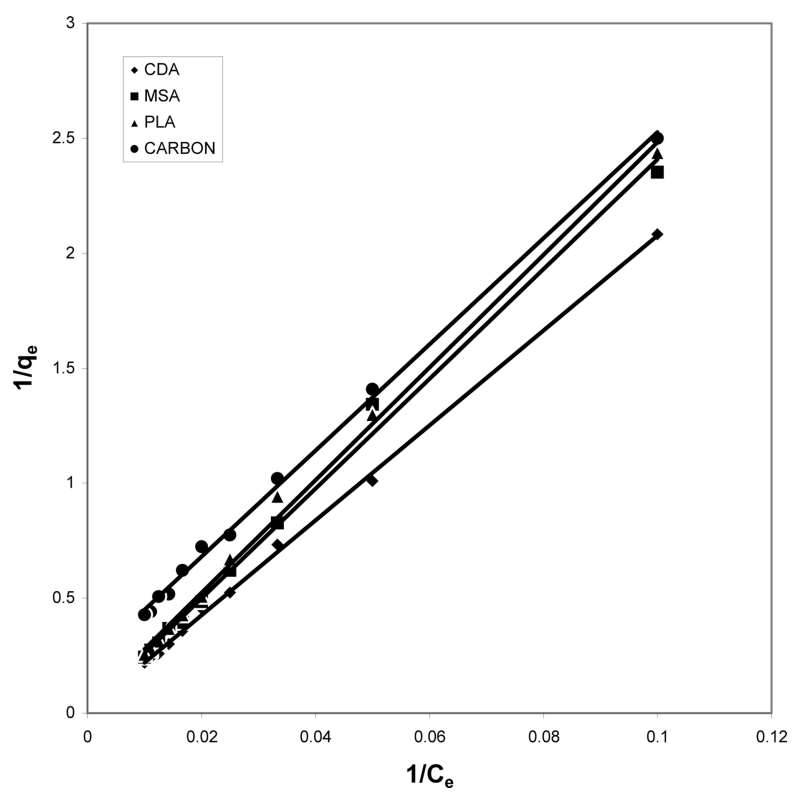

Fig. 8. Langmuir isotherm of Acid Blue 92 at pH 8.61.

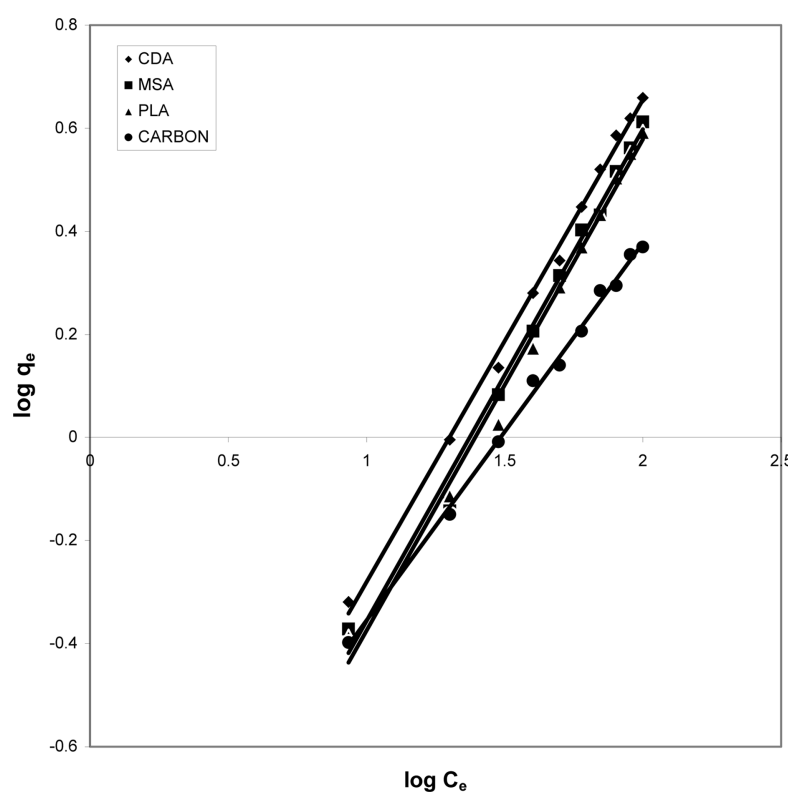

Fig. 9. Freundlich isotherm of Acid Blue 92 at $\mathrm{pH} 8.61$.

Table 2. Values of Different Constants for Polynomial Fit Data

\begin{tabular}{|c|c|c|c|c|c|c|c|c|c|c|c|c|}
\hline \multirow{3}{*}{ Parameter } & \multicolumn{3}{|c|}{ Cow dung ash } & \multicolumn{3}{|c|}{ Mango stone ash } & \multicolumn{3}{|c|}{ Parthenium leaves ash } & \multicolumn{3}{|c|}{ Carbon } \\
\hline & \multicolumn{3}{|c|}{$\mathrm{pH}$} & \multicolumn{3}{|c|}{$\mathrm{pH}$} & \multicolumn{3}{|c|}{$\mathrm{pH}$} & \multicolumn{3}{|c|}{$\mathrm{pH}$} \\
\hline & 6.90 & 4.95 & 8.61 & 6.90 & 4.95 & 8.61 & 6.90 & 4.95 & 8.61 & 6.90 & 4.95 & 8.61 \\
\hline $\mathrm{A}$ & 0.17633 & 55467 & 17783 & 10617 & 27267 & .03433 & 22067 & 0535 & 14333 & 0.076 & -0.03935 & 0.08333 \\
\hline $\mathrm{B}_{1}$ & 0.03481 & -0.0038 & 0.03137 & 0.02653 & 0.01137 & 0.04275 & 0.01103 & 0.04022 & 0.02433 & 0.03811 & 0.05411 & 0.0342 \\
\hline $\mathrm{B}_{2}$ & $1.85 \mathrm{E}-4$ & $7.90 \mathrm{E}-4$ & $3.39 \mathrm{E}-4$ & $3.29 \mathrm{E}-4$ & $6.14 \mathrm{E}-4$ & $-4.72 \mathrm{E}-5$ & $5.29 \mathrm{E}-4$ & $1.20 \mathrm{E}-4$ & $3.082 \mathrm{E}-4$ & $-3.74 \mathrm{E}-4$ & $-4.62 \mathrm{E}-4$ & $-1.61 \mathrm{E}-4$ \\
\hline $\mathrm{B}_{3}$ & $-8.2 \mathrm{E}-7$ & $-3.2 \mathrm{E}-6$ & $-2.1 \mathrm{E}-6$ & $-2.0 \mathrm{E}-6$ & $-3.4 \mathrm{E}-6$ & $3.19 \mathrm{E}-7$ & $-2.62 \mathrm{E}-6$ & $-4.53 \mathrm{E}-7$ & $-1.74 \mathrm{E}-6$ & $2.128 \mathrm{E}-6$ & $1.788 \mathrm{E}-6$ & $4.778 \mathrm{E}-7$ \\
\hline $\mathrm{R}^{2}$ & 0.99577 & 0.99463 & 0.99795 & 0.99455 & 0.99139 & 0.99748 & 0.99713 & 0.99973 & 0.99939 & 0.99725 & 0.98335 & 0.99319 \\
\hline SD & 0.11256 & 0.13503 & 0.0777 & 0.11261 & 0.14842 & 0.07629 & 0.08316 & 0.02987 & 0.03655 & 0.03786 & 0.10873 & 0.06626 \\
\hline
\end{tabular}




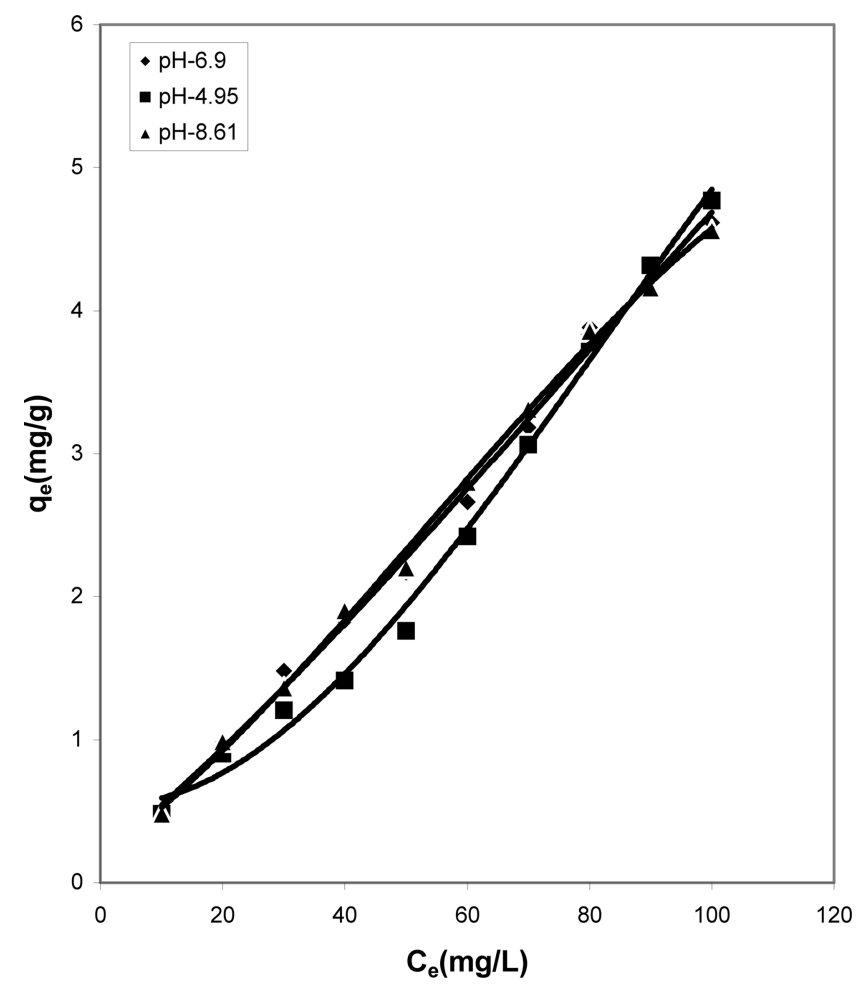

Fig. 10. Adsorption isotherm of Acid Blue 92 for cow dung ash at $\mathrm{pH} 6.90,4.95$ and 8.61 .

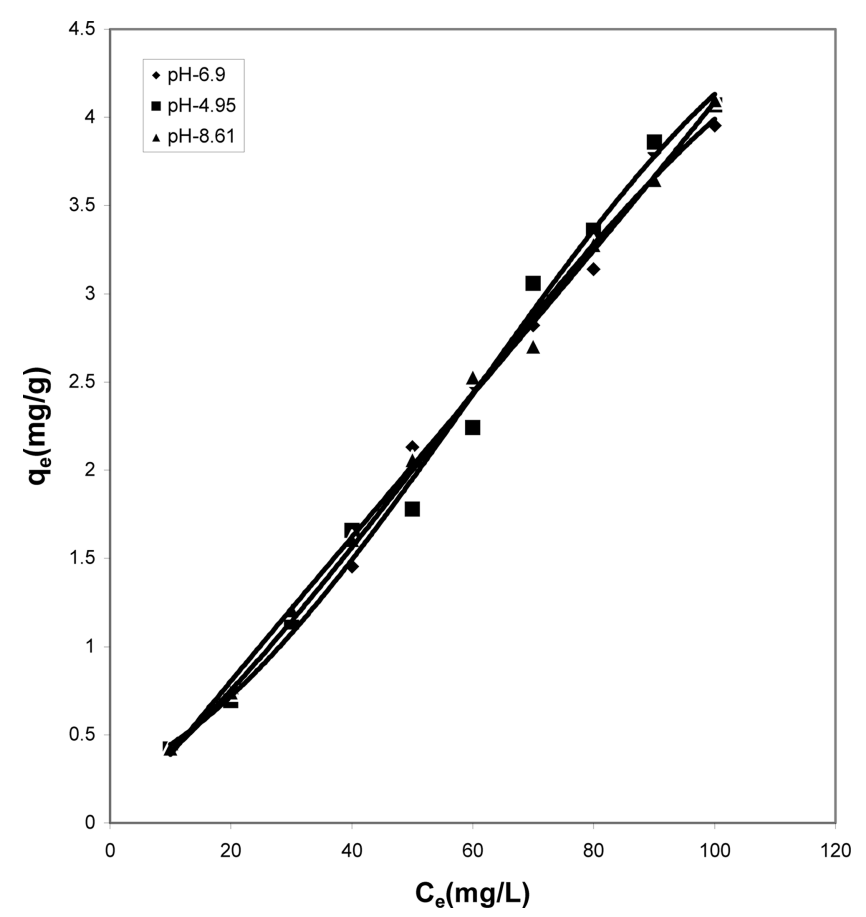

Fig. 11. Adsorption isotherm of Acid Blue 92 for mango stone ash at $\mathrm{pH} 6.90,4.95$ and 8.61.

than the neutral condition. But acidic solution favors better adsorption from other two $\mathrm{pH}$ values.

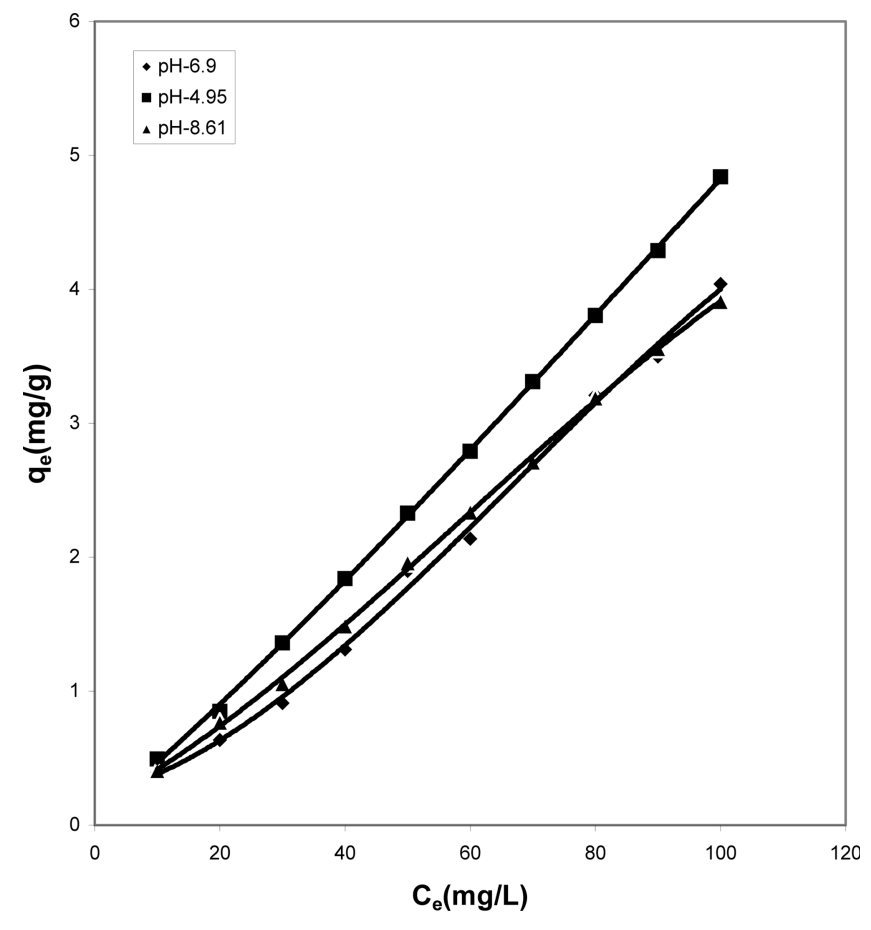

Fig. 12. Adsorption isotherm of Acid Blue 92 for parthenium leaves ash at $\mathrm{pH}$ 6.90, 4.95 and 8.61.

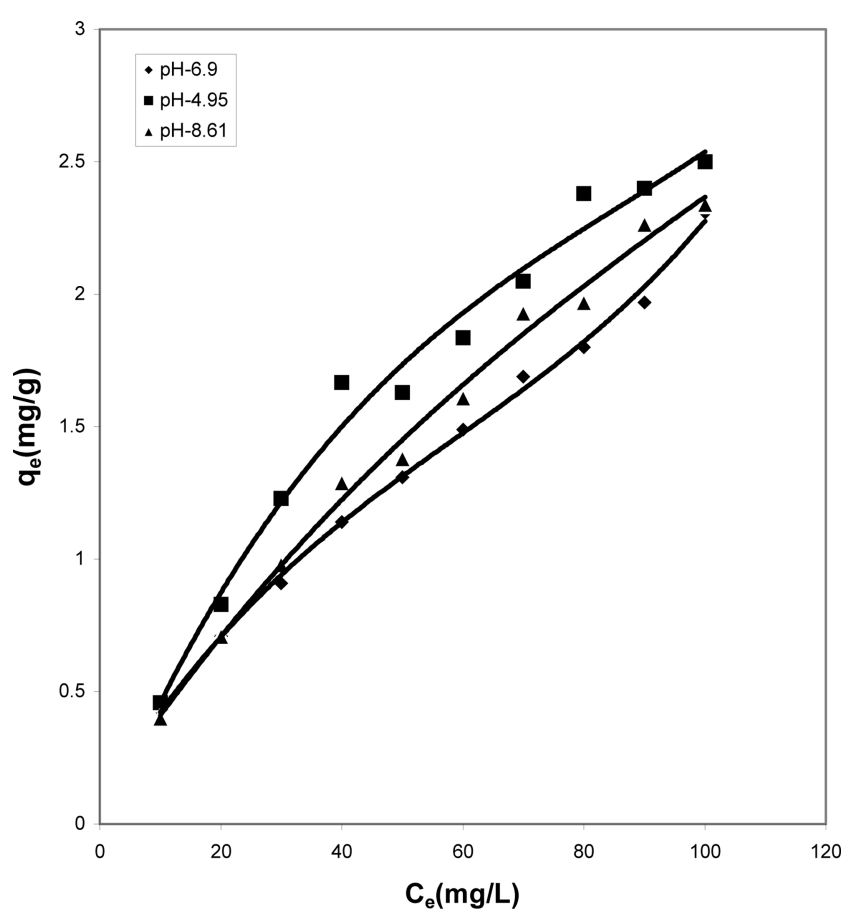

Fig. 13. Adsorption isotherm of Acid Blue 92 for carbon at $\mathrm{pH}$ $6.90,4.95$ and 8.61 .

\subsection{Langmuir isotherms at various $\mathrm{pH}$}

The data obtained was fitted to Langmuir isotherm as 


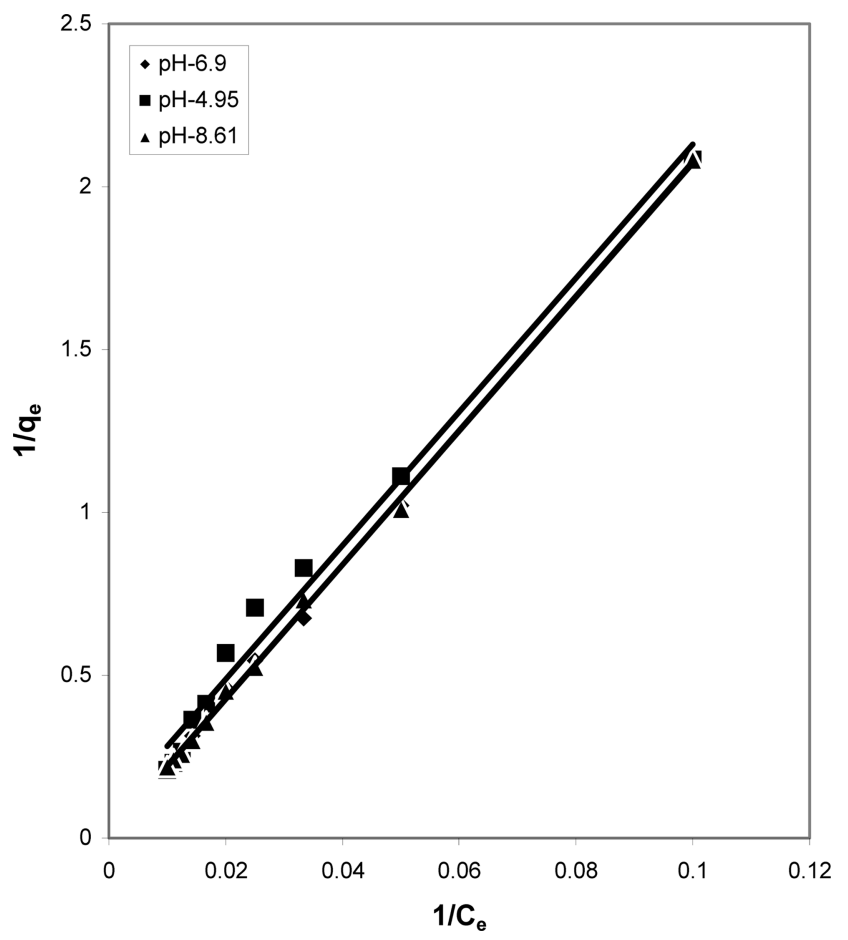

Fig. 14. Langmuir isotherm of Acid Blue 92 for cow dung ash at $\mathrm{pH} 6.90,4.95$ and 8.61 .

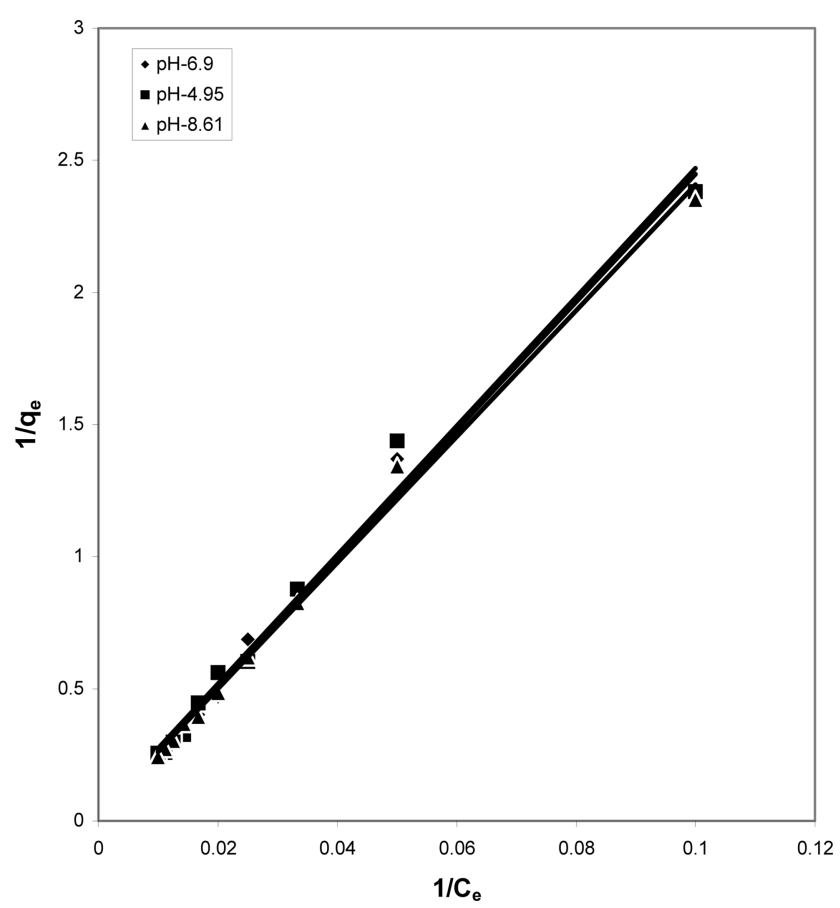

Fig. 15. Langmuir isotherm of Acid Blue 92 for mango stone ash at $\mathrm{pH} 6.90,4.95$ and 8.61.

shown in Figs. 2, 5 and 8 and also Figs. 14 17 for all the four adsorbents at three different $\mathrm{pH}$ values.

Table 3 gives the values of Langmuir constants "Q"

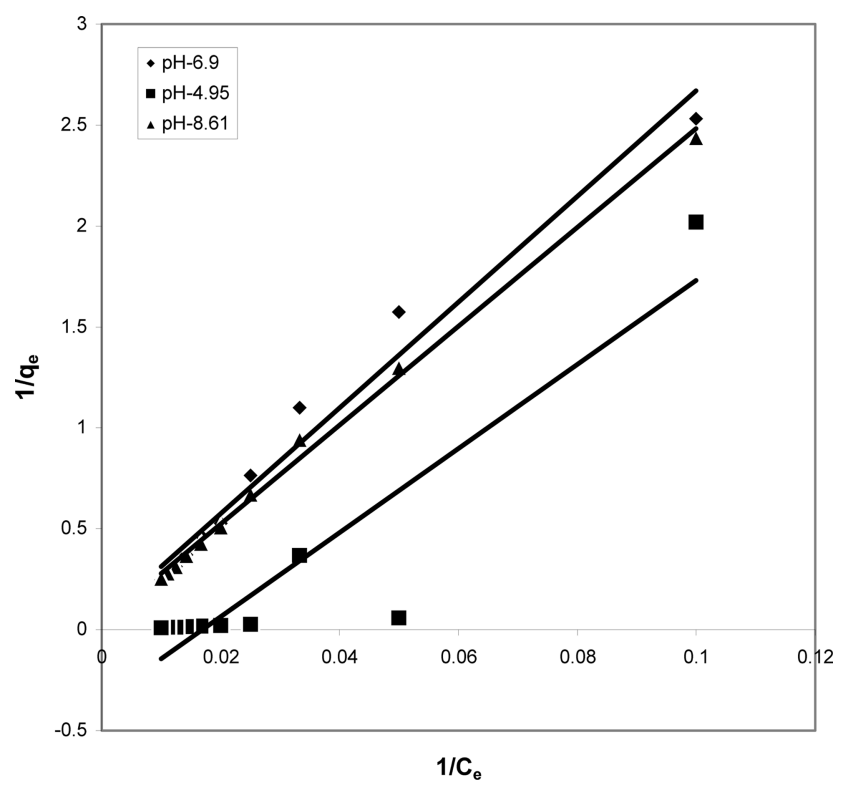

Fig. 16. Langmuir isotherm of Acid Blue 92 for parthenium leaves at $\mathrm{pH} 6.90,4.95$ and 8.61 .

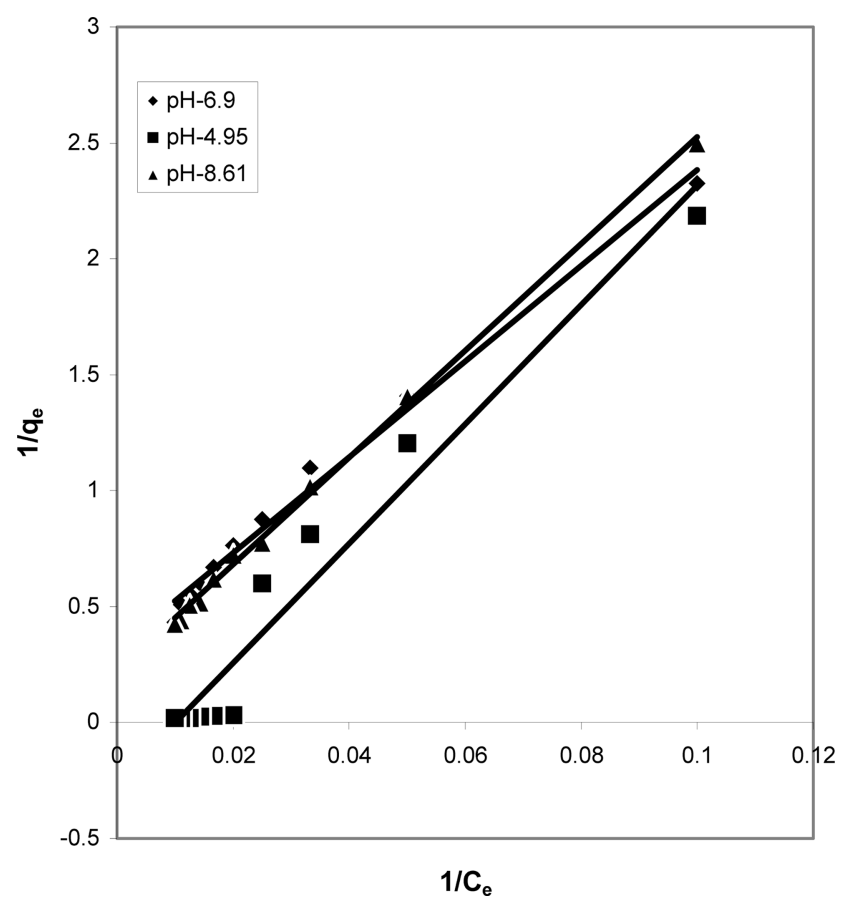

Fig. 17. Langmuir isotherm of Acid Blue 92 for carbon at $\mathrm{pH}$ $6.90,4.95$ and 8.61 .

(adsorption capacity in $\mathrm{mg} / \mathrm{g}$ ) and " $\mathrm{b}$ " (energy of adsorption in $\mathrm{mg} / \mathrm{L}$ ) along with the dimensionless separation factor $\mathrm{R}$ and standard deviation SD.

\subsection{Freundlich isotherm at various $\mathrm{pH}$}

The data was also fitted to the Freundlich isotherm as 
Table 3. Values of Different Constants for Langmuir Isotherms at Various $\mathrm{pH}$

\begin{tabular}{|c|c|c|c|c|c|c|c|c|c|c|c|c|}
\hline \multirow{3}{*}{ Parameter } & \multicolumn{3}{|c|}{ Cow dung ash } & \multicolumn{3}{|c|}{ Mango stone ash } & \multicolumn{3}{|c|}{ Parthenium leaves ash } & \multicolumn{3}{|c|}{ Carbon } \\
\hline & \multicolumn{3}{|c|}{$\mathrm{pH}$} & \multicolumn{3}{|c|}{$\mathrm{pH}$} & \multicolumn{3}{|c|}{$\mathrm{pH}$} & \multicolumn{3}{|c|}{$\mathrm{pH}$} \\
\hline & 4.95 & 6.90 & 8.61 & 4.95 & 6.90 & 8.61 & 4.95 & 6.90 & 8.61 & 4.95 & 6.90 & 8.61 \\
\hline $\mathrm{R}$ & 0.99279 & 0.99942 & 0.99945 & 0.99346 & 0.9962 & 0.9973 & 0.9178 & 0.98794 & 0.99815 & 0.97677 & 0.99512 & 0.99888 \\
\hline SD & 0.07287 & 0.02055 & 0.02007 & 0.08242 & 0.06168 & 0.05103 & 0.26491 & 0.12075 & 0.04378 & 0.16608 & 0.06026 & 0.03218 \\
\hline Q & 13.00390 & 63.3312 & 72.09805 & 32.8731 & 36.7242 & 43.3463 & 2.8256 & 19.8255 & 29.3341 & 3.85772 & 3.14366 & 4.57101 \\
\hline $\mathrm{b}$ & 1.57843 & 0.32484 & 0.28616 & 0.74182 & 0.659304 & 0.550187 & 7.37350 & 1.32138 & 0.83427 & 6.673116 & 6.57207 & 5.04680 \\
\hline
\end{tabular}

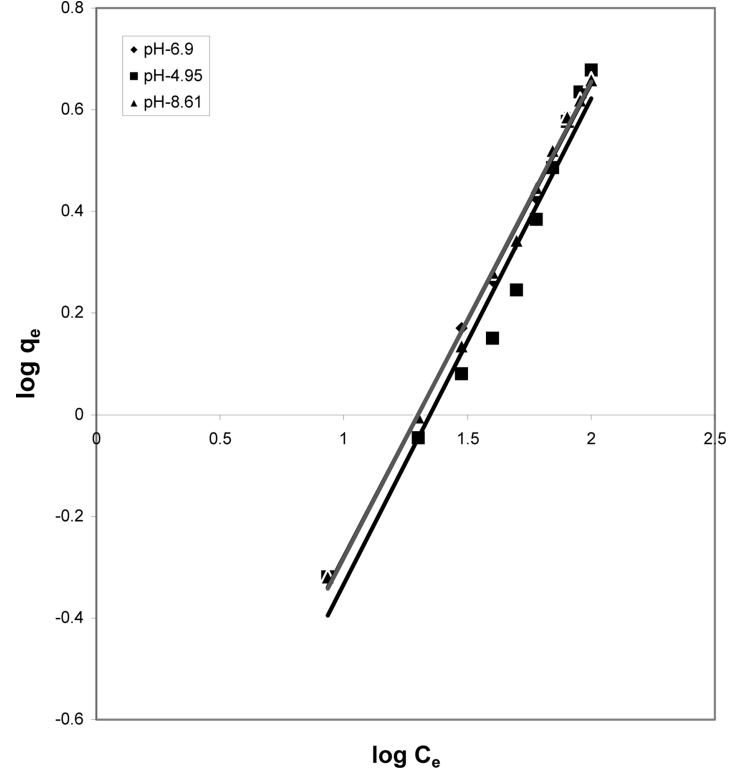

Fig. 18. Freundlich isotherm of Acid Blue 92 for cow dung ash at $\mathrm{pH} 6.90,4.95$ and 8.61 .

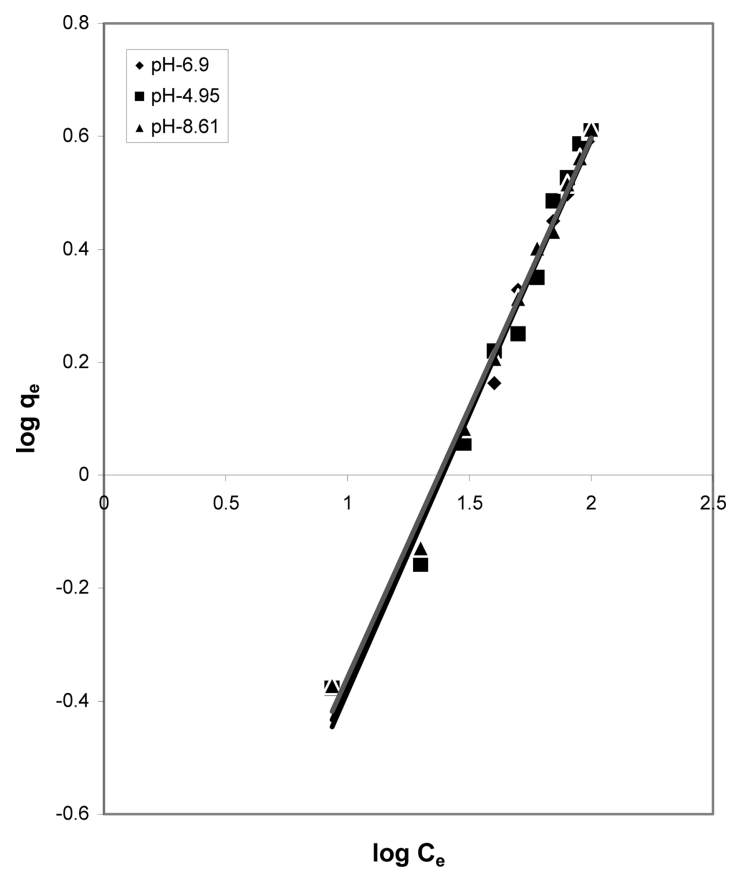

Fig. 19. Freundlich isotherm of Acid Blue 92 for mango stone ash at $\mathrm{pH} 6.90,4.95$ and 8.61 .

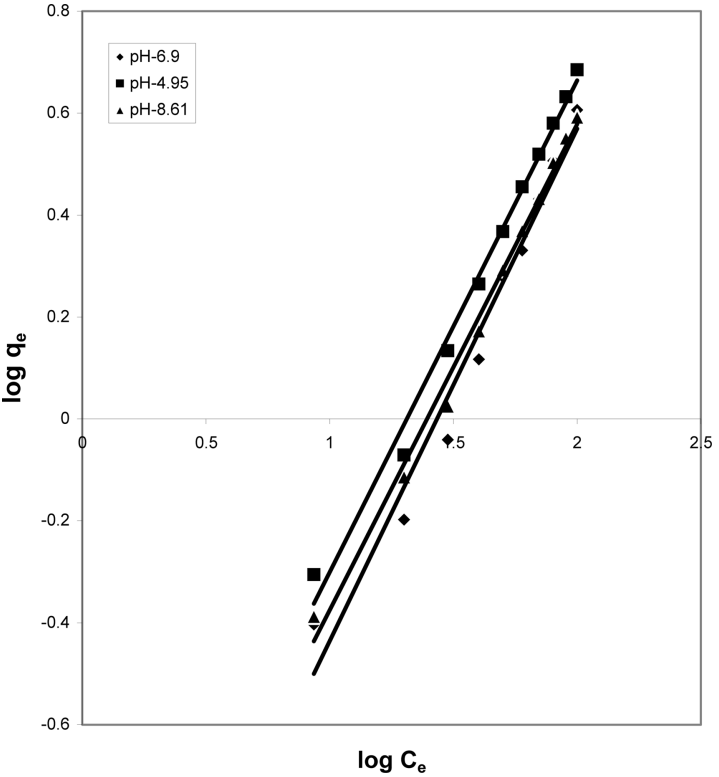

Fig. 20. Freundlich isotherm of Acid Blue 92 for parthenium leaves ash at $\mathrm{pH} 6.90,4.95$ and 8.61 .

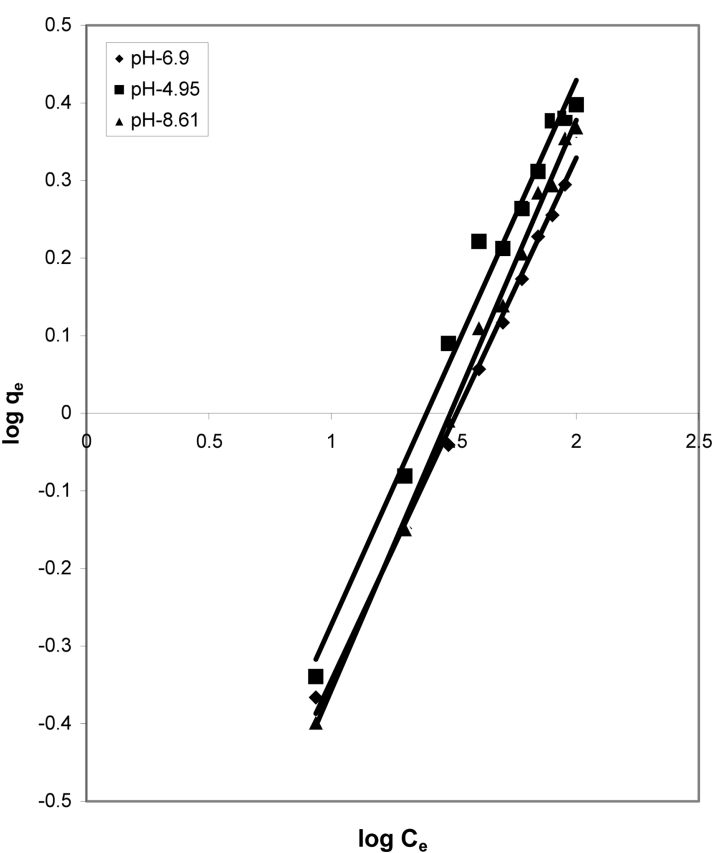

Fig. 21. Freundlich isotherm of Acid Blue 92 for carbon at $\mathrm{pH}$ $6.90,4.95$ and 8.61 . 
Table 4. Values of Different Constants for Freundlich Isotherms at Various pH

\begin{tabular}{|c|c|c|c|c|c|c|c|c|c|c|c|c|}
\hline \multirow{3}{*}{ Parameter } & \multicolumn{3}{|c|}{ Cow dung ash } & \multicolumn{3}{|c|}{ Mango stone ash } & \multicolumn{3}{|c|}{ Parthenium leaves ash } & \multicolumn{3}{|c|}{ Carbon } \\
\hline & \multicolumn{3}{|c|}{$\mathrm{pH}$} & \multicolumn{3}{|c|}{$\mathrm{pH}$} & \multicolumn{3}{|c|}{$\mathrm{pH}$} & \multicolumn{3}{|c|}{$\mathrm{pH}$} \\
\hline & 4.95 & 6.90 & 8.61 & 4.95 & 6.90 & 8.61 & 4.95 & 6.90 & 8.61 & 4.95 & 6.90 & 8.61 \\
\hline $\mathrm{R}$ & 0.98235 & 0.99779 & 0.99829 & 0.99096 & 0.99411 & 0.9962 & 0.9954 & 0.98688 & 0.99592 & 0.99145 & 0.99753 & 0.99816 \\
\hline SD & 0.06438 & 0.02196 & 0.01941 & 0.04699 & 0.0372 & 0.02948 & 0.03276 & 0.05815 & 0.03055 & 0.03261 & 0.01673 & 0.01578 \\
\hline $\mathrm{K}_{\mathrm{F}}$ & 0.275105 & 0.29734 & 0.29546 & 0.25543 & 0.26284 & 0.26941 & 0.28194 & 0.23658 & 0.264855 & 0.37810 & 0.36207 & 0.33628 \\
\hline $\mathrm{N}$ & 1.04540 & 1.07234 & 1.06697 & 1.01831 & 1.03600 & 1.04765 & 1.03594 & 0.99445 & 1.04898 & 1.42704 & 1.48727 & 1.36280 \\
\hline
\end{tabular}

shown in Figs. 3, 6 and 9 and also Figs. 18 21 at various pH values. Freundlich constants " $\mathrm{K}_{\mathrm{F}}$ " (adsorption capacity) and " $n$ " (process intensity) have also been calculated from the slope and intercept of $\log \mathrm{q}_{\mathrm{e}}$ and $\log \mathrm{C}_{\mathrm{e}}$ and their values along with $\mathrm{R}$ and standard deviation SD are given in Table 4.

\section{Conclusions}

The results obtained from the present investigation reveal the ability of various biomass ashes in treating dye effluents released from the tanneries for color removal. Adsorption of dye studied on various biomass ash and activated carbon shows that with increase in concentration of dye there is decrease in percentage removal of the dye per gram. Adsorption is highly dependent on $\mathrm{pH}$ and dye concentration. The adsorption isotherm of Acid Blue 92 onto the cow dung ash, mango stone ash, parthenium leaves ash and activated carbon is described by the Langmuir and Freundlich isotherm models. Judging by the value of $\mathrm{R}$ Langmuir isotherm gave a better fit for cow dung and mango stone ash whereas for parthenium leaves ash and activated carbon both the isotherms fitted equally well. The different values of $\mathrm{Q}$ are explained by the varying degree of interaction between the adsorbate and the adsorbent. These agriculture waste residues could therefore be substituted in place of activated carbon as adsorbent due to its availability, high adsorption capacity and low cost.

\section{References}

[1] Song, Z.; Williams, C. J.; Edyvean, R. G. J. Water Research 2000, 34, 2171.

[2] Pagga, U. M.; Taeger, K. Water Resour. Res. 1994, 28, 1051.

[3] O’Mahony, T.; Guibal, E.; Tobin, J. M. Enzyme Microbial Technology 2002, 31, 456.

[4] Bal, A. S. Ind. J. Environ. Hlth., 1999, 41, 264.

[5] Rajeshwari, S.; Sivakumar, S.; Senthilkumar, P.; Subburam, V. Bioresource Technol. 2001, 80, 233.

[6] Kadirvelu, K.; Kavipriya, M.; Karthika, C.; Radhika, M.; Vennilamani, N.; Pattabhi, S. Bioresource Technol, 2003, 87, 129.

[7] Low, K. S.; Lee C. K.; Heng, L. L. Environ. Technol. 1994, $15,115$.

[8] Churchley, J. H. Sci Tech. 1994, 30, 275.

[9] Weber Jr, W. J. "Physico-chemical Methods of Treatment of Water and Wastewater", New York, John Wiley \& Sons Inc, 1978.

[10] Choy, K. K. H.; McKay, G.; Porter, J. F. Resour. Conser. Rec. 1999, 27, 57. 